\title{
PENGARUH KEMAKMURAN PEMERINTAH DAERAH, UKURAN PEMERINTAH DAERAH, DAN TINGKAT KETERGANTUNGAN PEMERINTAH DAERAH TERHADAP KINERJA KEUANGAN PEMERINTAH
} KABUPATEN/KOTA DI PROVINSI ACEH

\author{
Rafika Aulia $^{1}$, Rahmawaty ${ }^{* 2}$ \\ ${ }^{1,2}$ Program Studi Akuntansi Fakultas Ekonomi Universitas Syiah Kuala \\ e-mail: rafikaaulia8470@ gmail.com ${ }^{1}$, rahmawaty@ unsyiah.ac.id ${ }^{* 2}$ \\ * Corresponding Author
}

\begin{abstract}
This study aims to examine the effect of regional government prosperity, local government size, and regional dependency level government on the financial performance of districts/city governments in Aceh Province. The population of this research is all districts and cities in Aceh Province, that as many as 23 districts/city in 2014-2018. This study uses secondary data with data collection techniques documentation methods. Statistical tests are performed with multiple linear regression analysis using SPSS program version 23. The result of the research shown that the regional government prosperity and local government size affect the financial performance of local governments while the regional dependency level government has no effect on the financial performance of local governments.
\end{abstract}

Keywords: Local Government Prosperity, Local Government Size, Regional Dependency Level Government, Financial Performance of Local Governments

\section{Pendahuluan}

Krisis ekonomi yang berlangsung di Indonesia pada awal tahun 1996 dan memuncak pada tahun 1997 telah menciptakan pendelegasian sebagian kekuasaan untuk pemerintah daerah dari pemerintah pusat mengenai pengelolaan keuangan, dengan harapan daerah dapat menangani pembangunan dan pelayanan secara mandiri. Pemberian desentralisasi dan otonomi yang luas memberikan kesempatan bagi pemerintah daerah yaitu kabupaten dan kota untuk terus berinovasi dalam mengelola anggaran dan keuangan daerahnya.

Setiap daerah memiliki hak untuk membentuk peraturan daerah, merencanakan, mengendalikan dan menjalankan kebijakan serta keuangan daerahnya sendiri adalah otonomi daerah (Sujarweni, 2015:231). Tujuan utama otonomi daerah adalah untuk memberikan layanan pemerintahan yang lebih baik dan meningkatkan akuntabilitas pemerintah daerah sehingga memicu pencapaian kesejahteraan masyarakat dengan cara meningkatan pelayanan yang diberikan ke masyarakat di daerah (Rusmin et al, 2014). Lewat kebijakan otonomi daerah tersebut keputusan untuk penyediaan pelayanan publik serta penyelenggaraan pemerintahan dapat diambil lebih cepat dan lebih sederhana mengingat pemerintah daerah dengan kewenangan yang dipunya lebih mengerti mengenai apa aspirasi dan apa kebutuhan masyarakat didaerahnya di bandingkan pemerintah pusat (Triani, 2015).

Pelaksanaan otonomi daerah tidak selalu berdampak positif, otonomi daerah juga menyebabkan ketimpangan di daerah dan permasalahan lainnya seperti ketidaksiapan pemerintah kabupaten/kota memenuhi harapan pemerintah pusat untuk dapat membiayai pembangunan daerahnya dengan Pendapatan Asli Daerah (Zamra \& Ernawati, 2019). Hal tersebut terjadi di salah satu daerah di Indonesia yaitu Provinsi Aceh yang masih menduduki peringkat provinsi termiskin di Sumatera dan keenam di Indonesia (www.news.detik.com). Berdasarkan data Badan Pusat Statistik (BPS) Aceh, penduduk yang tergolong miskin yang ada di Aceh mencapai 810.000 orang atau 15,01\% per September 2019. Provinsi Aceh berada pada posisi ke-6 setelah Provinsi Gorontalo 
(15,83\%), Maluku (17,85\%), NTT (21,03\%), Papua Barat $(22,66 \%)$ dan Papua $(27,43 \%)$.

Berdasarkan hasil analisis Lembaga Kajian Institute for Development of Acehnese Society (IDeAS) tingginya APBD di Provinsi Aceh masih belum mampu mengatasi persoalan angka kemiskinan di Provinsi Aceh (www.ajnn.com). Hal ini menjadi gambaran dari kinerja keuangan pemerintah daerahnya, mengingat evaluasi kinerja keuangan terhadap pengelolaan keuangan daerah bisa dilihat dari hasil penjabaran terhadap Anggaran Pendapatan Belanja Daerah (APBD) yang telah dibuat (Astuti, 2015). Menurut Widianto, et al (2015) apabila setiap daerah dapat memajukan berbagai potensi di sektor masing-masing maka Pendapatan Asli Daerah (PAD) akan meningkat dan mengurangi jumlah kemiskinan. Peningkatan PAD dapat mengurangi jumlah kemiskininan karena PAD yang diterima sebahagian dapat dialokasikan untuk mendukung programprogram pengentasan kemiskinan (Jolianis, 2016). Peningkatan PAD juga menunjukkan peningkatan kemakmuran di suatu daerah (Abdullah, 2004).

Menurut UU No. 23 Tahun 2014 tentang pemerintahan daerah, setiap pemerintah daerah diberi kesempatan untuk menjalankan kewenangan yang menjadi hukum daerahnya. Pemerintah daerah juga dapat menjajaki manfaat pembangunan daerahnya sesuai dengan ketentuan hukum. Pemerintah daerah diminta untuk produktif dan imajinatif dalam mengembangkan kemampuan daerah untuk memajukan kinerja daerahnya, baik kinerja non keuangan maupun kinerja keuangannya (Mustikarini \& Fitriasari, 2012).

Sularso dan Restianto (2011) memaparkan bahwa kemajuan yang diperoleh dari suatu daerah adalah hasil dari keberhasilan daerah tersebut dalam mengelola keuangannya. Pemerintah daerah memiliki kemampuan dalam hal mengelola keuangan tercermin pada Anggaran Pendapatan dan Belanja Daerah (APBD), seperti kesanggupan pemerintah untuk mendanai pembangunan, memaksimalkan pendapatan daerahnya, serta memajukan pelayanan sosial kepada masyarakatmya (Rondonuwu et al, 2015).

Laporan APBD setiap daerah bisa dijadikan tolak ukur dalam proses pembangunan daerah. Laporan tersebut dapat membantu masyarakat memeberikan penilaian tentang bagaimana kinerja pemerintah dalam mengelola keuangan daerahnya, sudahkah pengalokasian pendapatan sesuai dengan kebutuhan masyarakatnya atau belum (Aziz, 2016). Azlina dan Riantarno (2011) menyatakan pemerintah daerah dapat melakukan pengukuran kinerja keuangan daerahnya melalui APBD. Pengukuran kinerja dapat dilaksanakan dengan melihat capaian yang didapatkan dari periode ke periode berikutnya lalu dibandingkan. Penerapkan rasio keuangan terhadap APBD, yaitu rasio efisiensi, rasio efektifitas, rasio kemandirian dan rasio pertumbuhan adalah satu dari banyak parameter yang bisa digunakan untuk menjabarkan kinerja keuangan pemerintah daerah perihal mengatur keuangan daerahnya (Halim, 2008:230).

Pengukuran kinerja keuangan pemerintah daerah dalam riset ini yaitu rasio pertumbuhan dengan menggunakan komponen Belanja Modal sebagai pengukurannya. Semakin banyak infrastruktur yang dibangun dan sarana yang disediakan oleh pemerintah daerah adalah gambaran penggunaan belanja modal yang efektif. Pertumbuhan kinerja keuangan daerah akan meningkat apabila semakin banyak pembangunan (Nugroho dan Rohman, 2012).

Karakteristik pemerintah daerah juga dapat mempengaruhi kinerja keuangan pemerintah daerah. Karakteristik pemerintah daerah merupakan ciri-ciri tersendiri yang terdapat pada pemerintah daerah, yang menjadi ciri khas sebuah daerah, dan menjadi pembeda satu daerah dengan daerah lain. Kinerja keuangan dari pemerintah daerah dapat dipengaruhi oleh perbedaan karakteristik yang dimiliki oleh setiap daerah (Suhardjanto dan Yulianingtyas, 2011).

Berdasarkan riset Suryaningsih dan Sisdyani (2015), karakteristik pemerintah daerah dapat mempengaruhi kinerja keuangan pemerintah daerah yang mana karakteeristik tersebut berupa kemakmuran daerah, status daerah, belanja modal dan tingkat ketergantungan pemerintah daerah pada pemerintah pusat. Riset ini berbeda dengan riset Suryaningsih dan Sisdyani (2015) yang mana peneliti tidak menggunakan variabel independen status daerah dan belanja modal tetapi pada riset ini variabel independen yang digunakan adalah kemakmuran pemerintah daerah, ukuran pemerintah daerah dan tingkat ketergantungan pemerintah daerah.

Kemakmuran pemerintah daerah dapat diketahui dari total pendapatan asli daerahnya, semakin tinggi 
pendapatan asli daerah maka semakin makmur pula suatu daerah (Abdullah, 2004). Kemakmuran dapat diukur dengan perbandingan antara Pendapatan Asli Daerah (PAD) dan total pendapatan (Sudarsana, 2013).

Menurut Patrick (2007) ukuran pemerintah daerah diharapkan mampu meningkatkan kinerja keuangan pemerintah daerah. Semakin besar ukuran pemerintah daerah akan memudahankan kegiatan operasional yang tentunya juga melancarkan pelayananan kepada masyarakat (Kusumawardani,2012). Ukuran pemerintah daerah dapat diukur dari total aset yang dimiliki oleh pemerintah daerah (Sumarjo, 2010). Ukuran pemerintah daerah dapat meningkatkan pendapatan asli daerah secara tidak langsung, jikalau pemerintah berhasil memanfaatkan seluruh sumber potensi daerahnya serta mampu mengelola seluruh potensipotensi daerahnya dengan baik (Mulyani dan Wibowo, 2017).

Selain itu, faktor yang dapat mempengaruhi kinerja keuangan adalah tingkat ketergantungan pemerintah daerah dari pemerintah pusat yang tercermin dari seberapa besar perimbangan yang diterima oleh pemerintah daerah. Perbandingan antara total dana perimbangan dan total pendapatan digunakan sebagai indikator tingkat ketergantungan pemerintah daerah (Nugroho, 2012). Tingkat ketergantungan pemerintah daerah dapat diturunkan dengan penggunaan Pendapatan Asli Daerah untuk mendanai pembangunan (Nugroho, 2012). Darwanis dan Saputra (2014) juga berasumsi bahwa pendapatan daerah memiliki andil besar, karena melalui pendapatan daerah tersebut dapat diketahui kemampuan daerah dalam hal mendanai aktivitas pemerintahan serta pembangunan daerahnya, sehingga pemerintah daerah berkenan terus berupaya meningkatkan pertumbuhan kinerja keuangannya. Untuk itu dibutuhkan rasio pertumbuhan yang akan menunjukkan sebesar apa kemampuan dan bagaimana pemerintah daerah dapat bertahan, menambah serta terus melakukan peningkatan keberhasilan daerahnya dari waktu ke waktu.

Berdasarkan uraian tersebut, penulis tertarik untuk melakukan penelitian dengan mengambil judul "Pengaruh Kemakmuran Pemerintah Daerah, Ukuran Pemerintah Daerah dan Tingkat
Ketergantungan Pemerintah Daerah Terhadap Kinerja Keuangan Pemerintah Kabupaten/Kota di Provinsi Aceh."

\section{Tinjauan Pustaka}

Teori Keagenan

Menurut Jensen and Meckling (1976) keagenan merupakan semacam perjanjian antara principal dan agent, yaitu dengan pemberian beberapa kekuasaan kepada agen untuk pengambilan keputusan. Dalam organisasi publik, teori keagenan bisa dijalankan di negara dengan demokrasi baru yang lebih maju tentunya berdasarkan pada hubungan principal dan agent (Lane, 2000).

Masalah keagenan terdapat pada organisasi sektor publik maupun sektor privat. Masalah kegenan terjadi antara stakeholders dengan manajemennya dalam sektor privat, sedangkan dalam sektor publik masalah keagenan terjadi antara pemerintah sebagai agent dengan rakyat sebagai principal yang menyerahkan kekuasaan untuk dikelola oleh pemerintah dengan tujuan masyarakat diberikan pelayanan yang baik (Zimmerman, 1977). Pada dasarnya teori keagenan melatarbelakangi organisasi sektor publik, dibenarkan atau tidak faktanya terdapat hubungan dan masalah keagenan dalam pemerintah daerah (Halim dan Abullah, 2006).

Perilaku oportunistik (opportunistic behavior) merupakan dampak negatif dari teori keagenan. Hal ini berkaitan dengan permasalahan asimetri informasi, agen adalah pihak yang mempunyai informasi lebih banyak mengenai keuangan dari pada pihak prinsipal. Meskipun demikian, kewenangan/kekuasaan piihak prinsipal terkadang digunakannya untuk kepentingan pribadi (self-interest) (Abdullah dan Asmara, 2006). Conflict of interest akan muncul dalam teori keagenan yaitu sebuah representasi dari principal maupun agent yang mempunyai keinginan yang sama yaitu berjerih payah mencapai tujuan masing-masing (Jensen \& Meckling, 1976).

\section{Anggaran Pendapatan dan Belanja Daerah (APBD)}

Menurut Peraturan Pemerintah Republik Indonesia No. 12 Tahun 2019 Tentang Pengelolaan Keuangan Daerah, Anggaran Pendapatan dan Belanja Daerah (APBD) adalah rancangan yang dibuat setiap tahunnya mengenai keuangan pemerintah daerah yang 
dirundingkan dan disepakati oleh pemerintah daerah dan Dewan Perwakilan Rakyat Daerah (DPRD), dan disetujui dengan peraturan daerah. Anggaran Pendapatan dan Belanja Daerah (APBD) adalah alur pengelolaan keuangan daerah selama 1 (satu) tahun anggaran yang bisa menggambarkan kemampuan pemerintah daerah dalam hal mendanai kegiatan pemerintahan, baik itu pembangunan, dan pelayanan sosial bagi masyarakat.

Analisis rasio keuangan terhadap Anggaran Pendapatan dan Belanja Daerah (APBD) adalah satu dari banyak cara yang dilakukan untuk menganalisis kinerja pemerintah daerah dalam mengelola keuangan daerahnya apakah telah ditetapkan dan dilaksanakan dengan baik (Halim, 2004: 148).

\section{Laporan Keuangan Pemerintah Daerah (LKPD)}

Peraturan Pemerintah Republik Indonesia No. 71 Tahun 2010, menjelaskan bahwa Laporan Keuangan Pemerintah Daerah adalah penyajian informasi keuangan termasuk catatan terlampir jika ada, laporan keuangan ditujukan untuk mengomunikasikan sumber daya ekonomi (aset) dan/atau liabilitas suatu entitas pemerintah pada suatu waktu tertentu atau perubahan aset dan/atau liabilitas selama periode tertentu sesuai dengan Standar Akuntansi Pemerintahan.

Informasi yang berarti tentang posisi keuangan dan semua transaksi yang terjadi dalam sebuah entitas selama satu periode pelaporan disediakan dalam laporan keuangan. Informasi keuangan daerah yang dijadikan sebagai bahan evaluasi untuk pengambilan keputusan ekonomi, maupun sosial serta politik adalah tujuan digunakannya LKPD bagi pihak eksternal. Di sisi lain, laporan keuangan justru digunakan sebagai alat untuk penilaian kinerja bagi pihak internal pemerintah daerah (Surepno, 2013). Berdasarkan PP No. 71 Tahun 2010 laporan keuangan pokok terdiri dari:
a. Laporan Realisasi Anggaran (LRA)
b. Laporan Perubahan Saldo Anggaran Lebih (Laporan Perubahan SAL)
c. Neraca
d. Laporan Operasional (LO)
e. Laporan Arus Kas (LAK)
f. Laporan Perubahan Ekuitas (LPE)
g. Catatan atas Laporan Keuangan (CaLK)

\section{Kinerja Keuangan Pemerintah Daerah}

Dalam menjalankan otonomi daerah, kemampuan daerah dilihat dari pengukuran kinerja keuangan daerah (Halim, 2016:24). Besarnya tuntutan dari masyarakat kepada pemerintah daerah mengenai pertanggungjawaban kinerja keuangannya, mengharuskan pemerintah daerah memiliki kinerja yang baik. Untuk menilai baik buruknya kinerja pemerintah daerah dalam merencanakan, mengatur dan mengalokasikan keuangan daerahnya dapat dilakukan analisis rasio keuangan terhadap APBD (Sari, 2016).

Alur keuangan pemda berdasarkan laporan keuangan pemda bisa diidentifikasi dengan analisis kinerja keuangan (Darwanis dan Saputra, 2014). Proses peningkatan kinerja dari tingkat perencanaan sampai dengan tingkat evaluasi pecapaiannya akan diintegrasi dengan sistem pengukuran kinerja (Azhar, 2008). Pencapaian tujuan di masa depan dapat dengan mudah diraih apabila dilakukan upaya perbaikan secara terus menerus sebagai umpan balik dari sebuah pengukuran kinerja (Bastian, 2016).

Kinerja keuangan pemda dalam mengatur serta mengalokasikan persoalan keuangan di daerah dapat dianalisis dengan rasio keuangan terhadap APBD, rasio yang dimaksud yaitu rasio efisiensi, rasio rasio efektifitas, rasio kemandirian dan rasio pertumbuhan (Halim, 2008:230).

\section{Kemakmuran Pemerintah Daerah}

\begin{tabular}{ccc} 
Menurut & \multicolumn{2}{c}{ Kusumawardani (2012) } \\
kemakmuran adalah kemampuan yang harus
\end{tabular} dikembangkan untuk dapat memenuhi kebutuhan. Kemampuan tersebut diukur dengan Pendapatan Asli Daerah (PAD). Undang-Undang No. 33 Tahun 2004 menyatakan bahwa penggunaan PAD ditujukan untuk mendanai pembangunan di daerah karena Pendapatan Asli Daerah adalah kekayaan nyata dari setiap daerah, yang tujuan utamanya untuk mendanai kebutuhan daerahnya dan juga mengurangi tingkat ketergantungan pada pusat (Abdullah, 2004).

\section{Ukuran Pemerintah Daerah}

Besar atau kecilnya pemerintah yang ditunjukkan dengan besarnya aset pemerintah daerah disebut ukuran pemerintah daerah (Noviyanti \& Kiswanto, 2016). Ukuran pemda yang besar bisa 
meningkatkan pendapatan asli daerah secara tidak langsung, jikalau pemerintah sanggup mengelola dengan baik seluruh potensi-potensi daerahnya serta bisa memanfaatkan sumber-sumber potensi di daerahnya (Mulyani dan Wibowo, 2017).

Kemudahan kegiatan operasional akan melancarkan pemberian pelayanan kepada masyarakat apabila terdapat ukuran pemda yang besar. Menurut Sumarjo (2010) semakin besar ukuran pemda maka pemda akan lebih dituntut untuk mewujudkan pelayanan kepada masyarakat secara maksimal.

\section{Tingkat Ketergantungan Pemerintah Daerah}

Tingkat ketergantungan pemerintah daerah dapat dinyatakan dengan banyaknya dana perimbangan yang diserahkan oleh pusat kepada pemda. Untuk melaksanakan desentralisasi, dana yang berpokok dari APBN tersebut diberikan pada daerah guna membiayai kegiatan daerahnyan dana itu disebut dana perimbangan (Sumarjo, 2010).

Menurut Darwanto dan Yustikasari (2007) pemeberian dana perimbangan oleh pusat kepada daerah adalah resiko dari penyerahan kewenangan pemerintah pusat kepada daerah. Pemerintah pusat secara rutin mentransfer dana bantuan pada daerah yang nantinya akan digunakan secara mandiri oleh pemda untuk mewujudkan pelayanan kepada masyarakat atau untuk kepentingan lainnya.

\section{Metode Penelitian}

\section{Populasi dan Sampel Penelitian}

Populasi pada riset ini adalah semua pemerintahan kabupaten/kota di Provinsi Aceh. Dalam riset ini pengambilan sampel dilakukan dengan metode sensus yaitu metode pengambilam sampel semua populasi penelitian yakni semua kabupaten/kota yang terdapat di Provinsi Aceh yang berjumlah 23 kabupaten/kota. Nama-nama kabupaten/kota di Provinsi Aceh yang masuk dalam populasi penelitian ini dapat dilihat pada Tabel 3.1.

\section{Sumber dan Teknik Pengumpulan Data}

Sumber data pada riset ini adalah data sekunder. Data yang digunakan diambil dari Laporan Hasil Pemeriksaan (LHP) Laporan Keuangan Pemerintah Daerah (LKPD) oleh Badan Pemeriksa Keuangan
(BPK) Kabupaten/Kota di Provinsi Aceh tahun anggaran 2014-2018.

Metode dokumentasi adalah teknik yang digunakan untuk mengumpulkan data pada penelitian ini. Peneliti melakukan pencatatan, pengumpulan, dan pengolahan data yang bersumber dari data sekunder. Data penelitian tersebut terdiri atas laporan realisasi anggaran untuk memperoleh nilai dana perimbangan, PAD dan total realisasi anggaran pendapatan dan Neraca untuk mendapatkan total aset. Data LHP LKPD tersebut diperoleh langsung dari kantor BPK yang ada di Kota Banda Aceh.

Tabel 3.1

\section{Populasi Kabupaten/Kota}

\begin{tabular}{|c|l|}
\hline No & \multicolumn{1}{|c|}{$\begin{array}{c}\text { Nama-Nama Kabupaten/Kota di } \\
\text { Provinsi Aceh }\end{array}$} \\
\hline 1 & Kabupaten Aceh Barat \\
\hline 2 & Kabupaten Aceh Barat Daya \\
\hline 3 & Kabupaten Aceh Besar \\
\hline 4 & Kabupaten Aceh Jaya \\
\hline 5 & Kabupaten Aceh Selatan \\
\hline 6 & Kabupaten Aceh Singkil \\
\hline 7 & Kabupaten Aceh Tamiang \\
\hline 8 & Kabupaten Aceh Tengah \\
\hline 9 & Kabupaten Aceh Tenggara \\
\hline 10 & Kabupaten Aceh Timur \\
\hline 11 & Kabupaten Aceh Utara \\
\hline 12 & Kabupaten Bener Meriah \\
\hline 13 & Kabupaten Bireuen \\
\hline 14 & Kabupaten Gayo Lues \\
\hline 15 & Kabupaten Nagan Raya \\
\hline 16 & Kabupaten Pidie \\
\hline 17 & Kabupaten Pidie Jaya \\
\hline 18 & Kabupaten Simeulue \\
\hline 19 & Kota Banda Aceh \\
\hline 20 & Kota Langsa \\
\hline 21 & Kota Lhokseumawe \\
\hline 22 & Kota Sabang \\
\hline 23 & Kota Subulussalam \\
\hline
\end{tabular}

Sumber data: data diolah (2020)

\section{Operasionalisasi Variabel}

Variabel Dependen

Variabel dependen yang diteliti pada riset ini adalah kinerja keuangan pemerintah daerah. Indikator 
untuk mengevaluasi kinerja pemda adalah analisis kinerja keuangan. Satu dari banyak indikator yang dapat dijadikan pengukur kinerja keuangan pemerintah yaitu penerapan rasio keuangan terhadap APBD (Halim, 2008:230).

\section{Variabel Independen}

Variabel independen yang diteliti pada riset ini adalah kemakmuran pemerintah daerah, ukuran pemerintah daerah dan tingkat ketergantungan pemerintah daerah.

Untuk lebih jelasnya, operasionalisasi variabel pada penelitian ini dapat dilihat pada Tabel 3.2.

Tabel 3.2

Operasionalisasi Variabel

\begin{tabular}{|c|c|c|c|}
\hline Variabel & Indikator & Skala & Sumber \\
\hline $\begin{array}{c}\text { Kinerja } \\
\text { Keuangan } \\
\text { Pemerintah } \\
\text { Daerah }\end{array}$ & $\begin{array}{l}\text { Rasio Pertumbuhan Belanja Modal: } \\
\frac{\text { Belanja Modaltahun } p-\text { Belanja Modal tahun } p-1}{\text { BelanjaModaltahun } p-1} \times 100\end{array}$ & Rasio & $\begin{array}{l}\text { Halim } \\
(2008)\end{array}$ \\
\hline $\begin{array}{c}\text { Kemakmuran } \\
\text { Pemerintah } \\
\text { Daerah }\end{array}$ & $\frac{\text { Pendapatan Asli Daerah }}{\text { Total Pendapatan }}$ & Rasio & $\begin{array}{c}\text { Sudarsana } \\
\text { (2013) }\end{array}$ \\
\hline $\begin{array}{l}\text { Ukuran } \\
\text { Pemerintah } \\
\text { Daerah }\end{array}$ & Ln(Total Aset Pemerintah Daerah) & Rasio & $\begin{array}{l}\text { Sumarjo } \\
(2010)\end{array}$ \\
\hline $\begin{array}{c}\text { Tingkat } \\
\text { Ketergantung } \\
\text { an } \\
\text { Pemerintah } \\
\text { Daerah }\end{array}$ & $\frac{\text { Total Dana Perimbangan }}{\text { Total Pendapatan }}$ & Rasio & $\begin{array}{c}\text { Nugroho } \\
(2012)\end{array}$ \\
\hline
\end{tabular}

Sumber: Data diolah (2020)

\section{Metode Analisis dan Rancangan Pengujian Hipotesis}

Metode analisis data pada riset ini mencakup statistik deskriptif dan uji asumsi klasik. Statistik deskriptif disajikan guna mengamati karakterisasi data penelitian dengan cara saling menghubungankan antar variabel pada penelitian tersebut (Ardhani, 2011). Pengujian asumsi klasik pada penelitian ini yaitu uji normalitas, multikolinearitas, autokorelasi dan heteroskedastisitas.

1) Uji Normalitas

Alat yang dipakai untuk melakukan uji normalitas adalah Kolgomorov-Smirnov. Data dinyatakan berdistribusi normal apabila nilai signifikansi yang dimiliki variabel terikat lebih dari 0,05 (5\%). (Ghozali, 2011:160).
2) Uji Multikolinearitas

Pengujian multikolinearitas bisa dilakukan dengan menganalisis korelasi antar variabel dan perhitungan nilai toleransi serta variance inflation factor (VIF). Apabila nilai toleransi > 0,100 dan nilai VIF $<10$ dapat ditarik kesimpulan tidak terjadi multikolinearitas (Ghozali, 2011:105).

3) Uji Autokorelasi

Alat yang dipakai untuk melakukan uji autokorelasi adalah Durbin - Watson (DW). Pengambilan keputusan terjadi atau tidaknya autokorelasi dapat ditentukan jika nilai $\mathrm{du}<\mathrm{dw}<$ 4 - du (Ghozali, 2011:110).

4) Uji Heterokedastisitas

Untuk menguji terjadi atau tidaknya heterokedastisitas dalam model penelitian ini dapat dilakukan dengan menggunakan uji gleser. Heterokedastisitas tidak terjadi apabila secara statistik nilai variabel independen atau variabel bebas signifikan tidak mempengaruhi variabel dependen. Hal ini dapat dilihat jika probabilitas signifikansi diatas tingkat kepercayaan 5\% (Ghozali, 2011:143).

Pengujian hipotesis pada penelitian ini dilakukan dengan analisis regresi linear berganda yang diformulasikan sebagai berikut:

$$
\mathrm{Y}=\alpha+\mathrm{B} 1 \mathrm{X} 1+\mathrm{B} 2 \mathrm{X} 2+\mathrm{B} 3 \mathrm{X} 3+\mathrm{e}
$$

Keterangan:

$\mathrm{Y}$ = Kinerja Keuangan

$\mathrm{X} 1=$ Kemakmuran Pemerintah Daerah

$\mathrm{X} 2$ = Ukuran Pemerintah Daerah

X3 = Tingkat Ketergantungan Pemerintah Daerah

$\mathrm{B} 1=$ Koefisien regresi kemakmuran pemerintah daerah

B2 = Koefisien regresi ukuran pemerintah daerah

B3 = Koefisien regresi tingkat ketergantungan pemerintah daerah

A $=$ konstanta

$\mathrm{E}=$ error

\section{Koefisien Determinasi}

Apabila jumlah variabel $\mathrm{X}$ lebih dari dua dapat digunakan adjusted R2. Kisaran nilai R2 yaitu 0-1, jika R2 $=0$ dapat disimpulkan tidak ada korelasi antar variabel $\mathrm{Y}$ dan variabel $\mathrm{X}$, sebaliknya jika R2 $=1$ bisa 
ditarik kesimpulan terdapat korelasi yang sempurna antar variabel $\mathrm{Y}$ dan variabel $\mathrm{X}$.

\section{Uji F}

Pengujian ini dilakukan guna melihat pengaruh variabel bebas terhadap variabel terikat secara simultan. Jika nilai $\mathrm{F}_{\text {hitung }}>\mathrm{F}_{\text {tabel }}$ dengan tingkat signifikansi $5 \%$, maka hal ini menandakan bahwa secara bersama-sama atau simultan variabel bebas berpengaruh signifikan terhadap variabel terikat, begitu juga sebaliknya.

Uji T

Pengujian ini ditujukan guna melihat pengaruh variabel bebas secara tersendiri atau secara parsial dalam menjelaskan variabel terikat. Uji $T$ dilaksanakan dengan cara membandingkan hasil dari $t_{\text {hitung }}$ dan $t_{\text {tabel }}$, jika nilai $t_{\text {hitung }}>t_{\text {tabel }}$ dengan tingkat signifikansi $5 \%$ artinya variabel $\mathrm{X}$ secara parsial berpengaruh terhadap variabel $\mathrm{Y}$.

\section{Hasil dan Pembahasan}

\section{Deskripsi dan Analisa Data}

Data yang dikumpulkan pada riset ini merupakan data sekunder. Data tersebut yaitu Laporan Hasil Pemeriksaan (LHP) Laporan Keuangan Pemerintah Daerah (LKPD) Provinsi Aceh. Jumlah populasi pada riset ini adalah 23 kabupaten/kota di Provinsi Aceh. Peneliti memperoleh data secara langsung dari kantor BPK Aceh. Setelah memperoleh data LHP LKPD tersebut, data dihitung sesuai dengan pengukuran yang digunakan pada penelitian ini, selanjutnya ditabulasikan menggunakan Microsoft Excel 2010 dan diolah menggunakan SPSS versi 23.

\section{Hasil Pengujian Statistik Deskriptif}

Tabel 4.1

Hasil Uji Statistik Deskriptif

\begin{tabular}{|c|c|c|c|c|c|}
\hline Variabel & N & Minimum & Maximun & Mean & Std. Deviation \\
\hline $\mathrm{X} 1$ & 115 & 0,035 & 0,217 & 0,0876 & 0,03574 \\
\hline $\mathrm{X} 2$ & 115 & 27,059 & 29,990 & 28,3465 & 0,60192 \\
\hline $\mathrm{X} 3$ & 115 & 0,440 & 0,794 & 0,6480 & 0,06761 \\
\hline $\mathrm{Y}$ & 115 & $-66,001$ & 174,718 & 18,8230 & 51,22322 \\
\hline
\end{tabular}

Sumber: Data diolah (2020)

Pada Tabel 4.1 diketahui hasil pengujian statistik deskriptif dari variabel $\mathrm{X}$ dan $\mathrm{Y}$ untuk 115 sampel penelitian. Nilai mean kinerja keuangan pemerintah daerah di Provinsi Aceh dengan rasio pertumbuhan belanja modal adalah 18,8230. Berdasarkan kriteria kinerja keuangan, nilai rata-rata tersebut menunjukkan kinerja keuangan pemda di Provinsi Aceh sudah baik/positif. Nilai minimum untuk kinerja keuangan pemerintah daerah (Y) sebesar -66,001 yaitu pada Kabupaten Aceh Timur tahun 2018 sedangkan nilai maksimumnya sebesar 174,718 yaitu pada Kabupaten Aceh Tamiang tahun 2014. Kemakmuran pemerintah daerah (X1) memiliki nilai minimum sebesar 0,035 yaitu pada Kabupaten Pidie Jaya tahun 2017 sedangkan nilai maksimum sebesar 0,217 yaitu pada Kota Banda Aceh tahun 2017.

Nilai minimum untuk ukuran pemerintah daerah (X2) sebesar 27,059 yaitu pada Kabupaten Aceh Utara tahun 2015 sedangkan nilai maksimum sebesar 29,990 yaitu pada Kota Langsa tahun 2016. Nilai minimum untuk variabel tingkat ketergantungan pemerintah daerah (X3) sebesar 0,440 yaitu pada Kabupaten Pidie Jaya tahun 2017 sedangkan nilai maksimum sebesar 0,794 yaitu pada Kota Sabang tahun 2018.

\section{Hasil Uji Asumsi Klasik \\ Hasil Uji Normalitas}

Tabel 4.2

Uji Normalitas Kolgomorov-Smirnov

\begin{tabular}{|l|c|}
\hline & Unstandardized Residual \\
\hline Asymp. Sig. (2-tailed) & 0,200 \\
\hline
\end{tabular}

Sumber: Data diolah (2020)

Pada Tabel 4.2 diketahui nilai signifikansi (Asymp. Sig. 2-tailed) sebesar 0,200 atau < 0,05, yang artinya data pada riset ini berdistribusi normal.

\section{Gambar 4.1 Uji Normalitas}

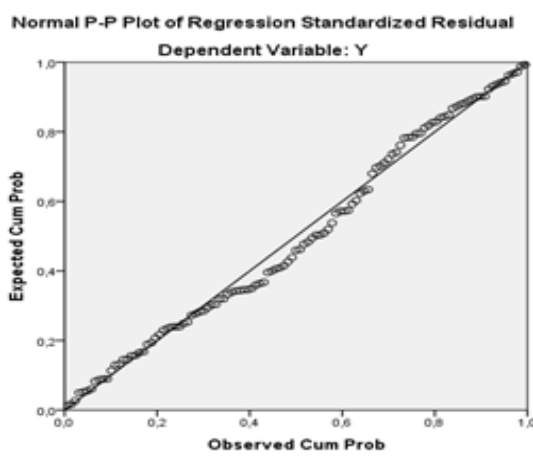

Sumber: Data diolah (2020) 
Pada gambar 4.1 diketahui grafik normal probability plot searah garis diagonalnya, yang artinya residual data berdistribusi normal.

\section{Hasil Uji Multikolinieritas}

Tabel 4.3

Hasil Uji Multikolinearitas

\begin{tabular}{|l|r|r|}
\hline \multicolumn{1}{|c|}{ Model } & \multicolumn{1}{c|}{ Tolerance } & \multicolumn{1}{c|}{ VIF } \\
\hline Kemakmuran Pemerintah Daerah & 0,920 & 1,087 \\
\hline Ukuran Pemerintah Daerah & 0,946 & 1,057 \\
\hline $\begin{array}{l}\text { Tingkat Ketergantungan Pemerintah } \\
\text { Daerah }\end{array}$ & 0,902 & 1,108 \\
\hline
\end{tabular}

Sumber: Data diolah (2020)

Pada Tabel 4.3, diketahui hasil uji multikolinearitas, setiap model pada riset ini memiliki nilai tolerance $>0,100$ dan nilai VIF $<10$ yang artinya pada riset ini tidak terdapat multikolinearitas.

\section{Hasil Uji Autokorelasi}

Tabel 4.4

Hasil Uji Autokorelasi

\begin{tabular}{|c|c|c|}
\hline Model & $\begin{array}{c}\text { Std. Error of } \\
\text { the Estimate }\end{array}$ & $\begin{array}{c}\text { Durbin- } \\
\text { Watson }\end{array}$ \\
\hline 1 & 45.281077 & 1.922 \\
\hline
\end{tabular}

Sumber: Data diolah (2020)

Pada Tabel 4.4 diketahui bahwa hasil uji autokorelasi melalui Durbin-Watson dalam riset ini senilai 1,922 , nilai tersebut terletak diantara nilai du dan 4 - du. Nilai du pada riset ini adalah 1.7496, sedangkan nilai 4-du pada riset ini adalah 2.2504, maka ditarik kesimpulan bahwa model regresi dalam riset ini tidak terjadi autokorelasi.

\section{Hasil Uji Heterokedasatisitas}

Tabel 4.5

Hasil Uji Heteroskedastisitas

\begin{tabular}{|l|r|}
\hline \multicolumn{1}{|c|}{ Model } & \multicolumn{1}{c|}{ Sig. } \\
\hline Kemakmuran Pemerintah Daerah & 0,980 \\
\hline Ukuran Pemerintah Daerah & 0,107 \\
\hline $\begin{array}{l}\text { Tingkat Ketergantungan Pemerintah } \\
\text { Daerah }\end{array}$ & 0,226 \\
\hline
\end{tabular}

Sumber: Data diolah (2020)
Pada Tabel 4.5 hasil uji heterokedastisitas untuk setiap model mempunyai nilai signifikan $>0,05$ yang artinya tidak terdapat gelasa heterokedastisitas. Pengujian heteroskedastisitas juga dapat dilakukan melalui pola pada grafik scatterplot. Pola grafik scatterplot pada riset ini dapat dilihat pada Gambar 4.2.

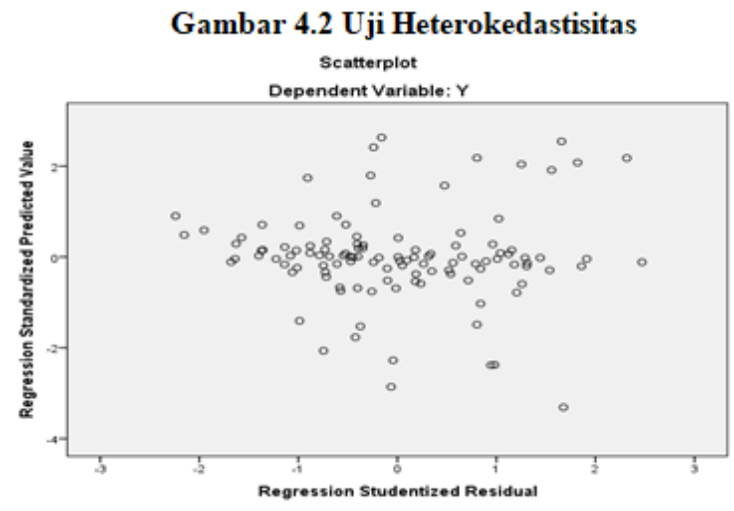

Sumber: Data diolah (2020)

Pada Gambar 4.2 diketahui tidak ditemukan pola tertentu, sebaran data dalam penelitian ini acak, yang artinya tidak terjadi heterokedastisitas pada penelitian ini.

\section{Hasil Pengujian Hipotesis}

\section{Hasil Uji Analisis Regresi Linear Berganda}

Tabel 4.6

Hasil Uji Analisis Regresi Linear Berganda

\begin{tabular}{|c|r|r|r|}
\hline \multirow{2}{*}{ Model } & \multicolumn{2}{|c|}{$\begin{array}{c}\text { Unstandardized } \\
\text { Coefficients }\end{array}$} & $\begin{array}{c}\text { Standardize } \\
\text { d } \\
\text { Coefficients }\end{array}$ \\
\cline { 2 - 4 } & \multicolumn{1}{|c|}{ B } & $\begin{array}{c}\text { Std. } \\
\text { Error }\end{array}$ & Beta \\
\hline \multicolumn{1}{|c|}{ (Constant) } & $-1188,245$ & 216,723 & \\
\hline Kemakmuran Pemerintah Daerah & $-246,679$ & 123,695 & $-0,172$ \\
\hline Ukuran Pemerintah Daerah & 40,887 & 7,245 & 0,480 \\
\hline $\begin{array}{l}\text { Tingkat Ketergantungan } \\
\text { Pemerintah Daerah }\end{array}$ & 107,116 & 66,030 & 0,141 \\
\hline
\end{tabular}

Sumber: Data diolah (2020)

Berdasarkan perhitungan statistik pada Tabel 4.6, dihasilkan sebuah persamaan regresi linear berganda sebagai berikut:

$$
Y=-1188,245-246,679 X 1+40,887 X 2+107,116 X 3
$$


Berdasarkan persamaan analisis regresi linear berganda yang dihasilkan, diketahui bahwa $-1188,245$ adalah nilai konstan. Nilai konstanta $-1188,245$ juga menunjukkan bahwa tiga variabel bebas menyumbangkan kontribusi yang besar guna mempengaruhi kinerja keuangan pemda sebesar kelipatan $-1188,245$. Nilai kemakmuran pemerintah daerah (X1) sebesar -246,679 dan negatif, artinya kemakmuran pemerintah daerah memberikan kontribusi negatif dalam mempengaruhi kinerja keuangan pemda. Apabila kemakmuran pemda meningkat maka kinerja keuangan pemda akan menurun.

Nilai ukuran pemerintah daerah (X2) sebesar 40,887 dan positif, artinya ukuran pemerintah daerah memberikan kontribusi positif dalam mempengaruhi kinerja keuangan pemda. Nilai tingkat ketergantungan pemerintah daerah (X3) sebesar 107,116 dan positif, artinya tingkat ketergantungan pemerintah daerah memberikan kontribusi positif dalam mempengaruhi kinerja keuangan pemda.

\section{Hasil Uji Koefisien Determinasi $\left(\mathbf{R}^{2}\right)$}

Tabel 4.7

Hasil Uji Koefisien Determinasi $\left(\mathrm{R}^{2}\right)$

\begin{tabular}{|c|c|c|c|}
\hline Model & $\mathrm{R}$ & R Square & $\begin{array}{c}\text { Adjusted } \mathrm{R} \\
\text { Square }\end{array}$ \\
\hline $\mathrm{l}$ & 0,489 & 0,239 & 0,219 \\
\hline
\end{tabular}

Sumber: Data diolah (2020)

Pada Tabel 4.7, diketahui nilai koefisien determinasi $\left(R^{2}\right)$ sebesar 0,239 atau 23,9\%. Nilai tersebut dapat dijelaskan oleh tiga variabel yaitu kemakmuran pemda, ukuran pemda, dan tingkat ketergantungan pemda sebesar $23,9 \%$. Sisanya sebesar 0,761 atau $76,1 \%$ diinterpretasikan oleh variabel lain yang tidak disertakan pada model riset ini.

\section{Hasil Pengujian secara Parsial (Uji T)}

Tabel 4.8

Hasil Pengujian secara Parsial

\begin{tabular}{|l|r|r|c|}
\hline \multicolumn{1}{|c|}{ Model } & \multicolumn{1}{c|}{ t } & \multicolumn{1}{c|}{ Sig. } & Kesimpulan \\
\hline \multicolumn{1}{|c|}{ (Constant) } & $-5,483$ & 0,000 & \\
\hline $\begin{array}{l}\text { Kemakmuran Pemerintah } \\
\text { Daerah }\end{array}$ & $-1,994$ & 0,049 & Berpengaruh \\
\hline Ukuran Pemerintah Daerah & 5,644 & 0,000 & Berpengaruh \\
\hline $\begin{array}{l}\text { Tingkat Ketergantungan } \\
\text { Pemerintah Daerah }\end{array}$ & 1,622 & 0,108 & $\begin{array}{c}\text { Tidak } \\
\text { Berpengaruh }\end{array}$ \\
\hline
\end{tabular}

Nilai $t_{\text {tabel }}$ dalam penelitian ini dicari menggunakan rumus $(\alpha / 2 ; \mathrm{n}-\mathrm{k}-1)=(0,05 / 2 ; 115-3$ $-1)=(0,025 ; 111)$, maka diperoleh nilai $t_{\text {tabel }}$ sebesar 1,981. Pada Tabel 4.8 bisa dilihat nilai $t_{\text {hitung }}$ untuk kemakmuran pemerintah daerah dan ukuran pemerintah daerah lebih dari nilai $t_{\text {tabel }}$ dengan tingkat signifikansi $<0,05$ yang artinya kemakmuran pemerintah daerah dan ukuran pemda berpengaruh terhadap kinerja keuangan pemda. Untuk tingkat ketergantungan pemda memiliki nilai $t_{\text {hitung }}<t_{\text {tabel }}$ yaitu $1,622<1,981$ dengan tingkat signifikansi 0,108 > 0,05 yang artinya tingkat ketergantungan pemda tidak berpengaruh terhadap kinerja keuangan pemda.

\section{Hasil Pengujian secara Simultan (Uji F)}

Tabel 4.9

Hasil Pengujian secara Simultan

\begin{tabular}{|c|c|c|c|c|c|}
\hline Model & $\begin{array}{c}\text { Sum of } \\
\text { Squares }\end{array}$ & $\begin{array}{c}\text { Df } \\
\text { Squan }\end{array}$ & F & Sig. \\
\hline Regression & 71553,859 & 3 & 23851,286 & 11,634 & 0,000 \\
\hline Residual & 227561,460 & 111 & 2050,103 & & \\
\hline Total & 299115,319 & 114 & & & \\
\hline
\end{tabular}

Sumber: Data diolah (2020)

Pada Tabel 4.9, diketahui hasil pengujian kemakmuran pemerintah daerah (X1), ukuran pemerintah daerah (X2), dan tingkat ketergantungan pemerintah daerah menunjukkan nilai $F_{\text {hitung }}$ sebesar 11,634 sedangkan nilai $F_{\text {tabel }}$ sebesar 2,69 yang artinya $\mathrm{F}_{\text {hitung }}>\mathrm{F}_{\text {tabel }}$, dengan tingkat signifikansi $0,000<0,05$ maka H1 diterima. Dapat ditarik kesimpulan variabel 
$\mathrm{X} 1, \mathrm{X} 2$, dan $\mathrm{X} 3$ berpengaruh secara simultan terhadap kinerja keuangan pemerintah daerah di Provinsi Aceh.

\section{Pembahasan}

Pengaruh Kemakmuran Pemerintah Daerah terhadap Kinerja Keuangan Pemerintah Daerah

Nilai signifikansi yang dihasilkan dari pengujian hipotesis untuk variabel kemakmuran pemerintah daerah menandakan bahwa kemakmuran pemda berpengaruh terhadap kinerja keuangan pemda.

Hasil riset ini didukung dengan hasil riset sebelumnya yaitu Sumarjo (2010), Mustikarini dan Fitriasasi (2012), Julitawati et al. (2012), Marfiana dan Kurniasih (2013), Marhawai (2015), Budianto dan Alexander (2016), Juwita (2016) Kusuma \& Handayani (2018), Puspita (2018), dan Novia dan Kartim (2019) yang menyatakan bahwa kemakmuran pemda berpengaruh terhadap kinerja keuangan pemda.

Persamaan analisis regresi linear berganda yang dihasilkan, menandakan bahwa kemakmuran pemda berpengaruh negatif signifikan terhadap kinerja keuangan pemerintah daerahnya, yang berarti jika semakin tinggi kemakmuran pemda maka akan semakin rendah kinerja keuangan pemerintah daerahnya. Hubungan negatif antara kemakmuran pemda yang dinyatakan dengan PAD dan kinerja keuangan pemda menjadi bukti bahwa adanya kecenderungan pemerintah daerah tidak menggunakan PAD sebagai sumber pendanaan kegiatan pemerintah daerahnya, baik itu kegiatan untuk masyarakat dan pembangunan yang ditandai dengan tingginya tingkat ketergantungan pemda pada pusat (Novia dan Kartim, 2019). Ini merupakan salah satu alasan yang menjadikan pemda tidak terdorong untuk menggali potensi-potensi kekayaan yang ada di daerahnya untuk dapat meningkatkan kemakmuran pemerintah daerah dan kinerja keuangannya karena pendanaan untuk kegiatan pemerintah daerah tidak bersumber dari PAD melainkan dana dari pemerintah pusat.

\section{Pengaruh Ukuran Pemerintah Daerah terhadap Kinerja Keuangan Pemerintah Daerah}

Nilai signifikansi dari hasil pengujian hipotesis menandakan ukuran pemda berpengaruh terhadap kinerja keuangan pemda.

Hasil riset ini didukung dengan hasil riset sebelumnya yaitu, Sumarjo (2010), Kusumawardani (2012), Marhawai (2015), Masdiantini \& Erawati
(2016), Sari (2016), Aziz (2016), Mulyani dan Wibowo (2017), Tama dan Adi (2018), dan Alvini (2018), Jauhari dan Dewata (2019) yang menyimpulkan bahwa ukuran pemda berpengaruh positif signifikan terhadap kinerja kinerja keuangan pemda. Hal ini ini menunjukkan semakin besar ukuran pemda yang ditandai oleh semakin besarnya total aset pemda, akan menjadikan kinerja keuangan pemda semakin baik.

Total aset yang dimiliki suatu daerah dapat memberikan kemudahan dalam kegiatan operasional daerahnya untuk memenuhi kewajiban pemerintah daerah yaitu memberikan pelyanan kepada masyarakat, seperti pembangunan jembatan, jalan, dan transportasi umum. Pelayanan masyarakat yang baik menunjukkan kinerja pemerintah daerah yang baik sehingga kinerja keuangannya juga baik.

\section{Pengaruh Tingkat Ketergantungan Pemerintah Daerah terhadap Kinerja Keuangan Pemerintah Daerah}

Nilai signifikansi dari hasil pengujian hipotesis menandakan bahwa tingkat ketergantungan pemda tidak berpengaruh terhadap kinerja keuangan pemda.

Hasil riset ini mendukung hasil riset sebelumnya yaitu, Harumiati dan Payamta (2014), Lestari (2019), dan Novia dan Kartim (2019) yang menyimpulkan bahwa tingkat ketergantungan pemda tidak berpengaruh terhadap kinerja keuangan pemda. Jadi dapat disimpulkan bahwa besarnya tingkat ketergantungan pemda yang diproksikan dengan dana perimbangan dari pusat tidak dimanfaatkan secara optimal yang berakibat besarnya tingkat ketergantungan pada pusat tidak memberikan pengaruh apapun pada kinerja keuangan pemerintah daerahnya.

Menurut Ernawati dan Jaeni (2018) dana perimbangan dari pusat sebagaian besar justru dipakai untuk belanja rutin aparatur daerah yang mengakibatkan tidak tersedianya dana untuk pelayanan publik dan menyebabkan ketidakefektifan penggunaan dana perimbangan. 


\section{Kesimpulan dan Saran}

\section{Kesimpulan}

Berikut adalah kesimpulan pada riset ini dari hasil analisis data, pengujian hipotesis dan pembahasan yang dijabarkan sebelumnya:

1) Kemakmuran pemerintah daerah, ukuran pemerintah daerah dan tingkat ketergantungan pemerintah daerah secara simultan berpengaruh terhadap kinerja keuangan pemerintah daerah di Provinsi Aceh.

2) Kemakmuran pemerintah daerah berpengaruh terhadap kinerja keuangan pemerintah daerah di Provinsi Aceh.

3) Ukuran pemerintah daerah berpengaruh terhadap kinerja keuangan pemerintah daerah di Provinsi Aceh.

4) Tingkat ketergantungan pemerintah daerah tidak berpengaruh terhadap kinerja keuangan pemerintah daerah di Provinsi Aceh.

\section{Keterbatasan}

Penelitian ini memiliki keterbatasan yaitu:

1) Variabel $X$ pada riset ini tidak menggambarkan keseluruhan faktor-faktor yang memberikan pengaruh pada kinerja keuangan pemda.

2) Data penelitian ini sangat terbatas, hanya sebatas pada kabupaten/kota di Provinsi Aceh.

3) Data pada riset ini tidak seluruhnya tersedia di website resmi pemda di Provinsi Aceh, yang mana mengharuskan peneliti secara langsung datang ke kantor BPK Aceh untuk mengambil data yang dibutuhkan.

4) Data penelitian yang digunakan hanya dari periode 2014-2018, dikarenakan data untuk periode 2019 belum seluruhnya tersedia di kantor BPK Aceh.

5) Riset ini menggunakan rasio pertumbuhan belanja modal untuk mengukur kinerja keuangan pemda, rasio tersebut belum banyak digunakan oleh penelitian sebelumnya, sehingga tidak banyak referensi yang mendukung.

\section{Saran}

Saran praktis meliputi:

1) Pemerintah daerah sebaiknya lebih memfokuskan tujuan untuk memajukan kinerja keuangan daerahnya dengan menggali potensi dan kemampuan daerah sehingga memperoleh PAD yang maksimal khususnya mengutamakan pembangunan SDA dan SDM di setiap daerah, guna meningkatkan perekonomian daerahnya.

2) Pemerintah daerah di Provinsi Aceh juga diminta mampu memanfaatkan secara maksimal dana perimbangan yang diserahkan oleh pemerintah pusat, agar tingkat ketergantungan yang tinggi dapat meningkatkan kinerja keuangan pemda, mengingat dana yang diserahkan oleh pusat dimaksudkan meningkatkan pelayanan publik dan juga kinerja keuangan pemerintah daerahnya.

Saran akademis meliputi:

1) Penelitian selanjutnya diharapkan menambah variabel bebas lainnya guna memperluas hasil empiris pengaruh terhadap kinerja keuangan pemerintah daerah.

2) Penelitian selanjutnya juga diharapkan menggunakan LKPD tahun berikutnya agar penelitian memiliki hasil yang terbaru, dan sebaiknya juga menambah tahun penelitian, tidak hanya 5 tahun agar diperoleh hasil yang lebih lengkap.

3) Penelitian selanjutnya lebih baik jangan terpaku dengan data yang bersumber dari data sekunder saja tetapi juga memperoleh data yang bersumber dari data primer agar data penelitian lebih akurat.

\section{Daftar Pustaka}

Abdullah, S. (2004). Perilaku Oportunistik Legislatif dalam Penganggaran Daerah: Pendekatan Principal-Agency Theory. Fakultas Ekonomi Universitas Bengkulu.

Abdullah, S \& Asmara, J.A. (2006). Perilaku Oportunistik Legislatif dalam Penganggaran Daerah: Bukti Empiris atas Aplikasi Agency Theory di sektor publik. Proceding Simposium Nasional Akuntansi IX Volume 9, Padang.

Aceh Journal National Network. (2019). APBD Aceh Tertinggi Ke-5, Angka Kemiskinan Masih Tertinggi Ke-6 Di Indonesia. (https://www.ajnn.net/news/apbd-aceh-tertinggi- 
ke-5-angka-kemiskinan-masih-tertinggi-ke-6-diindonesia/index.html). Diakses pada 5 Mei 2020 .

Adi, P. H. (2006). Hubungan Antara Pertumbuhan Ekonomi, Belanja Pembangunan Dan Pendapatan Asli Daerah. Proceding Simposium Nasional Akuntansi XI Padang.

Alvini, Y. (2018). Pengaruh Ukuran Pemerintah Daerah, Tingkat Kekayaan Daerah, Tingkat Ketergantungan Daerah Kepada Pemerintah Pusat dan Belanja Modal Terhadap Kinerja Keuangan Pemerintah Daerah (Studi pada Kabupeten/Kota se- Provinsi Riau Periode (2011)-(2016)). JOM FEB, 1 (1), hal.1-15.

Andirfa, M., Basri, H., dan M. Shabri A. Majid. (2016). Pengaruh Belanja Modal, Dana Perimbangan, dan Pendapatan Asli Daerah Terhadap Kinerja Keuangan Kabupaten dan Kota di Provinsi Aceh. Jurnal Magister Akuntansi Pascasarjana Universitas Syiah Kuala, 5 (3), hal.30-38.

Anzarsari, D. (2014). Pengaruh Karakteristik Pemerintah Daerah Terhadap Kinerja Pemerintah Daerah (Studi Empiris Pada Kabupaten/Kota Se-Jawa Tengah). Skripsi. Fakultas Ekonomi dan Bisnis. Universitas Muhammadiyah Surakarta.

Ardhani, P. (2011). Pengaruh Pertumbuhan ekonomi, Pendapatan Asli Daerah, Dana Alokasi Umum, dan Dana Alokasi Khusus terhadap Pengalokasian Anggaran Belanja Modal (Studi pada Pemerintah Kabupaten /Kota di Jawa Tengah). Skripsi. Semarang: Universitas Diponegoro.

Azhar, MHD Karya Satya. (2008). Analisis Kinerja Keuangan Pemerintahan Daerah Kabupaten /Kota Sebelum Dan Setelah Otonomi Daerah. Tesis. Medan.

Aziz, A. (2016). Pengaruh Karakteristik Pemerintah Daerah Terhadap Kinerja Keuangan Pemerintah Daerah ( Studi Pada Pemerintah Daerah Kabupaten / Kota Di Jawa Timur ). EKSIS Universitas Islam Majapahit Mojokerto. ISSN: 1907-7513, 11(1).
Badan Litbang Depdagri RI dan FISIPOL-UGM. (1991). Pengukuran Kemampuan Keuangan Daerah Tingkat II Dalam Rangka Otonomi Daerah Yang Nyata Dan Bertanggung Jawab. Jakarta.

Bastian, I. (2016). Akuntansi Perbankan. Edisi Pertama. Jakarta:Salemba Empat

Budianto \& Stanly W Alexander. (2016). Pengaruh PAD dan Dana Perimbangan Terhadap Kinerja Keuangan Pemerintah Kabupaten/Kota di Provinsi Sulawesi Utara. JURNAL EMBA, 4 (4), hal.844-851.

Darwanis \& Saputra, R. (2014). Pengaruh Belanja Modal Terhadap Pendapatan Asli Daerah dan Dampaknya pada Kinerja Keuangan Pemerintah Daerah. Jurnal Dinamika Akuntansi dan Bisnis, 1 (2), hal.183199.

Darwanto \& Yustikasari, Y. (2007). Pengaruh Pengaruh Pertumbuhan Ekonomi, Pendapatan Asli Daerah, Alokasi Umum terhadap Pengalokasian Belanja Modal. Proceding Simposium Nasional Akuntansi $X$, Unhas Makassar.

Ernawati \& Jaeni. (2018). Faktor Penentu Kinerja Keuangan Pemerintah Daerah Kabupaten/Kota di Provinsi Jawa Tengah. Dinamika Akuntansi, Keuangan dan Perbankan, 7(1), 73-81.

Florida, A. (2007). Pengaruh Pendapatan Asli Daerah (PAD) Terhadap Kinerja Keuangan Pemerintah Kabupaten dan Kota Di Propinsi Sumatera Utara. Tesis Program Studi Ilmu Akuntansi Universitas Sumatera Utara, Medan.

Ghozali, I. (2011). Aplikasi Analisis Multivariate Dengan Program SPSS. Semarang: Universitas Diponegoro.

Halim, A. (2004). Akuntansi Sektor Publik Akuntansi Keuangan Daerah. Salemba Empat. Jakarta.

(2008). Akuntansi Keuangan Daerah. Jakarta: Salemba Empat.

(2012). Akuntansi Sektor Publik: Akuntansi Keuangan Daerah. Jakarta: Salemba Empat. 
. (2014). Manajemen Keuangan Sektor Publik

Problematika Penerimaan dan Pengeluaran Pemerintah (Anggaran Pendapatan dan Belanja Negara/ Daerah). Jakarta: Salemba Empat.

(2016). Akuntansi Sektor Publik Akuntansi Keuangan Daerah. Salemba Empat.

Halim, A, \& Abdullah, S. (2006). Hubungan dan Masalah Keagenan di Pemerintah Daerah: (Sebuah Peluang Penelitian Anggaran dan Akuntansi). Jurnal Akuntansi Pemerintahan, 2(1), 53-64.

Harumiati, Y \& Payamta. (2014). Pengaruh Karakteristik Pemerintah Daerah Dan Temuan Audit BPK Terhadap Kinerja Penyelenggara Pemerintah Daerah Kabupaten/Kota di Indonesia Tahun Anggaran 2011. Jurnal Akuntansi dan Pendidikan, 3(2), 75-87.

Jauhari, H \& Dewata, E. (2019). The Determinant Factors of Performance of Provincial Governments in Indonesia. Journal of Accounting and Business Education, 3 (2), 170179.

Jensen, M.C \& Meckling, W. (1976). Theory of the Firm : Managerial Behaviour, Agency Cost and Ownership Structure. Journal of Financial Economics, 3 (4), 305-360.

Jolianis. (2016). Analisis Pengaruh PAD, DAU Dan DAK Terhadap Kemiskinan Pada Kabupaten/Kota Di Provinsi Sumatera Barat Dengan Pertumbuhan Ekonomi Sebagai Variabel Intervening. Journal of Economic and Economic Education, 4 (2), 192-209.

Julitawati, E., Darwanis., dan Jalaluddin. (2012). Pengaruh Pendapatan Asli Daerah (PAD) dan Dana Perimbangan Terhadap Kinerja Keuangan Pemerintah Kabupaten/Kota di Provinsi Aceh. Jurnal Akuntansi, 1(1), 15-29.

Juwita, R. (2016). Pengaruh Pendapatan Asli Daerah Terhadap Kinerja Keuangan Daerah (Studi Kasus pada Kabupaten/Kota di Provinsi Banten Tahun (2012)- (2015)). SEMNAS FEKOM, 1 (1), 608-616.
Kusumawardani. (2012). Pengaruh Size, Kemakmuran, Ukuran Legislatif, Leverage terhadap Kinerja Keuangan Pemerintah Daerah di Indonesia. Accounting Analysis Journal 1. Universitas Negeri Semarang.

Kusuma, A. R., \& Handayani, N. (2017). Pengaruh Karakteristik Pemerintah Daerah Terhadap Efisiensi Kinerja Keuangan Pemerintah Daerah. Jurnal Ilmu dan Riset Akuntansi 6(1), 403-420.

Lane, J.E. (2000). New Public Management. Routledge, London.

Lestari, L. (2019). Pengaruh Karakteristik Pemerintah Daerah Terhadap Kinerja Keuangan Pemerintah Daerah Kabupaten/Kota di Provinsi Sumatera Selatan. Skripsi. Fakultas Ekonomi dan Bisnis Universitas Muhammadiyah Palembang.

Mardiasmo. (2001). Pengawasan, Pengendalian dan Pemeriksaan Kinerja Pemerintah Dalam Melaksanakan Otonomi Daerah. Jurnal Bisnis dan Akuntansi, 3(2).

\section{(2002). Akuntansi Sektor Publik.} Yogyakarta: CV Andi Offset. (2016). Pengukuran Kinerja Sektor Publik. Yogyakarta: BPFE.

Marfiana, N., \& Kurniasih, L. (2013). Pengaruh Karakteristik Pemerintah Daerah dan Hasil Pemeriksaan Audit BPK Terhadap Kinerja Keuangan Pemerintah Daerah Kabupaten / Kota. Journal \& Proceeding Universitas Jenderal Soedirman, 3(1), 1-16.

Marhawai. (2015). Pengaruh Ukuran Legislatif, Kemakmuran Pemerintah Daerah, Ukuran Pemerintah Daerah dan Intergovernmental Revenue terhadap Kinerja Keuangan Pemerintah Daerah (Studi Pada Kabupaten/Kota Di Aceh Tahun 2010 s.d 2014). Jurnal Telaah dan Riset Akuntansi, 8(1), 49-58.

Masdiantini, P. R., \& Erawati, N. M. (2016). Pengaruh Ukuran Pemerintah Daerah, Kemakmuran, Intergovernmental Revenue, Temuan Dan Opini Audit Bpk Pada Kinerja Keuangan. E-Jurnal 
Akuntansi Universitas Udayana,14(2), 11501182 .

Mulyani, S., \& Wibowo H. (2017). Pengaruh Belanja Modal, Ukuran Pemerintah Daera, Intergovernmental Revenue dan Pendapatan Asli Daerah terhadap Kinerja Keuangan. Kompartemen, 15 (1), 57-66.

Mustikarini, W A \& Fitriasasi, D. 2012. Pengaruh Karakteristik Pemerintah Daerah dan Temuan Audit BPK Terhadap Kinerja Pemerintah Daerah Kabupaten/Kota di Indonesia Tahun Anggaran 2007. Proceding Simposium Nasional Akuntansi 15.

Novia, R \& Kartim. (2019). Pengaruh Size, Wealth, Leverage, dan Intergovernmental Revenue terhadap Kinerja Keuangan Pemerintah Provinsi Papua. Accounting Journal Universitas Yapis Рариа, 1(1), 29-37.

Noviyanti, N. A., \& Kiswanto. (2016). Pengaruh Karakteristik Pemerintah Daerah, Temuan Audit Bpk Terhadap Kinerja Keuangan Pemerintah Daerah. Accounting Analysis Journal, 5(1), 110.

Nugroho, F. (2012). Pengaruh Belanja Modal terhadap Pertumbuhan Kinerja Keuangan Daerah dengan Pendapatan Asli Daerah sebagai Variabel Intervening. Skripsi Universitas Diponegoro Semarang.

Nugroho, F \& Rohman, A. (2012). Pengaruh Belanja Modal Terhadap Pertumbuhan Kinerja Keuangan Daerah dengan Pendapatan Asli Daerah Sebagai Variabel Intervening. Diponegoro Journal of Accounting, 1(2), 1-14.

Nurdin, F.( 2014). Pengaruh Karakteristik Pemerintah Daerah Dan Temuan Audit BPK RI Terhadap Akuntabilitas Kinerja Pemerintah Daerah. Jurnal Mahasiswa FEB.

Patrick, P. A. (2007). The Determinant of Organizational Inovativeness: The Adoption of GASB 34 in Pennsylvania Local Government. Unpublished Ph.D Dissertation. Pennsylvania: The Pennsylvania State University.
Piliang, Markon. (2020). Merangkul Aceh Demi Keutuhan Dan Kemakmuran Bangsa. (https://www.suarakarya.id/detail/105798/Mera ngkul-Aceh-Demi Keutuhan-Dan-KemakmuranBangsa). Diakses pada 23 Desember 2019.

Puspita, A. P. (2018). Analisis PAD dan Dana Perimbangan Terhadap Kinerja Keuangan Pemdah Se-Jawa Barat. Jurnal Akuntansi\& Ekonomi FE, 3(1), 80-96.

Republik Indonesia. Peraturan Pemerintah Nomor 12 Tahun 2019 Tentang Pengelolaan Keuangan Daerah. . Peraturan Pemerintah No. 71 Tahun 2010 Tentang Standar Akuntansi Pemerintahan. Undang-Undang Nomor 23 Tahun 2014 Tentang Pemerintahan Daerah.

Undang-Undang Nomor 33 Tahun 2004 tentang Pemerintahan Daerah Perimbangan Keuangan antara Pemerintahan Pusat dan Pemerintahan Daerah.

Undang-undang Nomor 17 Tahun 2003 Tentang Keuangan Negara.

Riantiarno, R \& Azlina N. (2011). Faktor-faktor yang mempengaruhi kinerja instansi pemerintah (Studi pada Satuan Perangkat Daerah Kabupaten Rokan Hulu). Pekbis, Jurnal, 3(3).

Rondonuwu, R H., Jantje J. T., \& Budiarso N. (2015). Analisis Efisiensi dan Efektifitas Pengelolaan Keuangan Daerah pada Dinas Pendapatan Daerah Kabupaten Minahasa. Jurnal EMBA, 3 (4), 23-32

Rusmin, R., Astami, Emita W., \& Scully, G. (2014). Local Government Units in Indonesia : Demographic Attributes and Differences in Financial Condition. Australasian Accounting Business and Finance Journal, 8(2), 88-109.

Sari, I P. (2016). Pengaruh Ukuran Pemerintah Daerah, PAD, Leverage, Dana Perimbangan dan Ukuran Legislatif Terhadap Kinerja Keuangan Pemerintah Daerah (Studi Pada Kab/Kota Pulau Sumatra). JOM Fekon, 3 (1), 679-692. 
Sebastiana dan Cahyo, H. (2016). Analysis of Economic Performance as the Independence Indicators of Government in East Java Province. Review of Integrative Business \& Economics Research, 5 (2), 272-285.

Sekaran, U \& Bougie, R. (2018). Metode Penelitian untuk Bisnis Pendekatan PengembanganKeahlian. Jakarta. Salemba Empat.

(2019). Metode Penelitian untuk Bisnis Pendekatan Pengembangan-Keahlian. Jakarta. Salemba Empat.

Sudarsana, H S. (2013). Pengaruh Karakteristik Pemerintah Daerah Dan Temuan Audit BPK Terhadap Kinerja Pemerintah Daerah. E-journal sl.undip.ac.id/index.php/accounting, 2(4), 1-13.

Sugiyono. (2016). Metode Penelitian Kuantitatif, Kualitatif dan $R \& D$. Bandung: PT Alfabet.

Suhardjanto, D., Hartoko, S., Retnoningsih, H., Rusmin, M., Putriesti dan Brown, A. (2011). Influence of Parliament Characteristics toward Mandatory Accounting Disclosure Compliance in Indonesia. Accounting Forum (China), 19 (1), 3-16.

Suhardjanto, D \& Yuliningtyas, R R. 2011. Pengaruh Karakteristik Pemerintah Daerah Terhadap Kepatuhan Pengungkapan Wajib dalam Laporan Keuangan Pemerintah Daerah. Jurnal Akuntansi dan Auditing, 8 (1), 1- 94.

Sujarweni, V W. (2015). Akuntansi Desa: Panduan Tata Kelola Keuangan Desa. Jakarta : Pustaka Baru Press.

Sularso, H dan Restianto Y E. (2011). Pengaruh Kinerja Keuangan Terhadap Alokasi Belanja Modal dan Pertumbuhan Ekonomi Kabupaten/Kota di Jawa Tengah. Media Riset Akuntansi, 1 (2), 109-124.

Sumarjo, H. (2010). Pengaruh Karakteristik Pemerintah Daerah Terhadap Kinerja Keuangan Pemerintah Daeah (Studi Empiris Pada Pemerintah Daerah Kabupaten/Kota Di Indonesia. Skripsi. Surakarta: Fakultas Ekonomi, Universitas Sebelas Maret Surakarta.
Surepno. (2013). Pengaruh return on equity (roe), ukuran (size) dan kemakmuran (wealth) pemerintah daerah terhadap kinerja keuangan pemerintah daerah di Indonesia. Skripsi. Semarang: Fakultas Ekonomi Universitas Negeri Semarang.

Tama, A, A \& Adi, P, H. (2018). Pengaruh Karakteristik Kepala Daerah, Ukuran Pemerintah, dan Temuan Audit terhadap Kinerja Keuangan Daerah. Perspektif Akuntansi, 1(1), 91-113.

Taufiq, Nuri. (2020). Fakta-Fakta Seputar Aceh Sebagai Provinsi Termiskin Di Sumatra (https://news.detik.com/kolom/d-4877496/faktafakta-seputar-aceh-sebagai-provinsi-termiskindi-sumatera). Diakses pada 23 Desember 2019.

Triani, M. (2015). Analisis Kebijakan Otonomi Daerah Terhadap Pertumbuhan Ekonomi Di Sumatera Barat Dalam Menghadapi Masyarakat Ekonomi ASEAN. Seminar Nasional Ekonomi Manajemen Dan Akuntansi (SNEMA) Fakultas Ekonomi Universitas Negri Padang.

Widianto, A., Sari, P Y., \& Hertika. (2015). Pengaruh Pendapat Asli Daerah Terhadap Belanja Modal, Pertumbuhan Ekonomi, Dan Kemiskinan Kabupaten/Kota Di Daerah Istimewa Yogyakarta. Independent Researcher: Politeknik Harapan Bersama Tegal.

Zamra, S \& Ernawati. (2019). Perkembangan Kabupaten Solok setelah otonomi daerah tahun 1998-2019. JRTI (Jurnal Riset Tindakan Indonesia), 4(2), 53-58.

Zimmerman, L. J. (1977). The Municipal Accounting Maze: An analysis of political incentives. Journal Accounting Research, 15, 107-144. 